\title{
Chronic feeding with protein-restricted diets affect ileal amino acid digestibility and the expression of nutrient-sensing, hormone secretion, gastrointestinal digestive enzyme, and nutrient transporter genes in young weaned pigs
}

\author{
Li Wu ${ }^{1,2, *}$, Peng Liao ${ }^{1, *}$, Qinghua $\mathrm{He}^{2, *}$, Bie Tan $^{1}$, Feifei Guo ${ }^{3}$, Min Tang ${ }^{4}$ and Tiejun Li ${ }^{1}$ \\ ${ }^{1}$ Institute of Subtropical Agriculture, Chinese Academy of Sciences, Changsha, Hunan Province 410125, China \\ ${ }^{2}$ Department of Food Science and Engineering, College of Chemistry and Environmental Engineering, Shenzhen University, \\ Shenzhen 518055, China \\ ${ }^{3}$ Longyan Taimai and Sanluck Pharmaceutical Co., LTD., Longyan, Fujian Province 366215, China \\ ${ }^{4}$ Department of Gynaecology and Obstetrics, Mawangdui District of Hunan Provincial People's Hospital, Changsha, Hunan \\ Province 410016, China \\ "These authors contributed equally to this work \\ Correspondence to: Peng Liao, email: liaopeng@isa.ac.cn \\ Min Tang, email: enid0568@163.com \\ Tiejun Li, email: tjli@isa.ac.cn
}

Keywords: weaned pigs; protein restriction diets; amino acid; nutrient-sensing; digestive enzyme

Received: November 16, $2017 \quad$ Accepted: January 02, $2018 \quad$ Published: January 09, 2018

Copyright: Wu et al. This is an open-access article distributed under the terms of the Creative Commons Attribution License 3.0 (CC BY 3.0), which permits unrestricted use, distribution, and reproduction in any medium, provided the original author and source are credited.

\section{ABSTRACT}

The aim of this work was to investigate the serum biochemical profile, ileal amino acid (AA) digestibility, and expression of nutrient-sensing, hormone secretion, gastrointestinal (GIT) digestive enzyme and nutrient transporter genes in pigs subjected to dietary protein restriction. Twenty-four weaned pigs were distributed into three treatments, and the animals in each treatment were fed crude protein (CP) diets at one of three levels $(20,17$, and $14 \%)$. Our results showed that pigs fed the $20 \%$ CP diet had greater $(P<0.05)$ average daily gain and ratio of feed to gain than those fed the $14 \%$ CP diet, but there were no differences between the $20 \%$ CP and $17 \%$ CP diets. Additionally, the $20 \%$ CP diet tended to upregulate $(P<0.05)$ the expression of nutrient-sensing-related genes, such as taste receptor type 1 member 1 (TasR1), calcium-sensing receptor (CaSR), and solute carrier family 1 (EAAC1), and the $17 \%$ CP diet tended to up-regulate $(P<0.05)$ the expression of digestive enzyme-related genes, hormone secretion-related genes, and nutrient transporter-related genes, such as pepsinogen, cholecystokinin type A receptor (CCK-1R), and dipeptide transporter 1 (PepT1), respectively. These results suggested that weaned pigs that were chronically fed a moderately restricted $17 \%$ CP protein diet could catch up to pigs fed a $20 \%$ CP diet in terms of growth performance and feed efficiency. In conclusion, the provision of $20 \%$ dietary CP was beneficial to the expression of nutrient-sensing and nutrient transporter genes in the GIT, and the provision of $17 \%$ dietary CP was beneficial to lipid metabolism and digestive enzymes in the GIT. 


\section{INTRODUCTION}

Young mammals (including infant and weaned pigs) have often been reported to exhibit gastrointestinal tract (GIT) dysfunction, including alterations intestinal morphology, the immune system, and absorption functions, when fed a high-protein diet [1-5]. A reduction in dietary crude protein (CP) levels can reduce diarrhea and nitrogen $(\mathrm{N})$ excretion and repair digestive and immune function by enhancing the gene expression levels of digestive enzymes and amino acid (AA) transporters in young pigs $[4,6]$. For weaned pigs, it has been suggested that the CP levels in their diets can be reduced by $2-3$ points without affecting average daily gain (ADG) $[4,6]$, feed efficiency, or gastrointestinal health when the diets are supplemented with AAs [7, 8]. However, reductions exceeding 3 points have produced no effects on ADG, feed efficiency and the mRNA levels of digestive enzymes (including trypsinogen, chymotrypsin B, and dipeptidaseII and III) and AA transporters [2, 4, 9-13], although these trends have not been observed in all studies [14-16]. These findings suggest that the reduction of dietary CP levels and supplementation with AAs may be an alternative method for decreasing $\mathrm{N}$ excretion and improving GIT digestive function while maintaining performance in young pigs. The level of dietary CP is a major issue in livestock production that impacts the economy and the environment. Therefore, the present work was principally focused on the impact of dietary CP levels on the regulation of the digestion, absorption, and metabolism of nutrients (for example, AAs, glucose, and lipids) in the GIT, along with feed intake.

The digestion and absorption of dietary CP involves complex mechanical disruption and enzymatic breakdown in the stomach, followed by further enzymatic breakdown by pancreatic proteases in the duodenum and jejunum, resulting in a substance from which hydrolysated oligopeptides and free AAs can be readily absorbed and, finally, the conversion of nutrients to animal tissue to maintain the early stage of growth after weaning $[17,18]$. To efficiently digest and absorb nutrients from ingested food, these events are regulated by nutrient-sensing receptors and the secretion of the GIT hormones gastrin and cholecystokinin (CCK) following the secretion of digestive enzymes and the expression of AA transporters [4, 9-11, 19-21]. The identification of these receptors or their signaling elements in the GIT mucosa indicates that these receptors may play roles in nutrient-sensing and, potentially, hormone secretion [22]. Nutrient-sensing receptors such as members of the taste 1 receptor family (for example, TasR1, TasR2, and TasR3), gene and protein expression of the free fatty acid receptor family (for example, GPR40, GPR41, and GPR43, also known as FFAR1, FFAR2, and FFAR3, respectively), $\mathrm{G}$ protein-coupled receptor class $\mathrm{C}$ group
6 member A (GPRC6A), and calcium-sensing receptor (CaSR), hormones such as somatostatin (SST), ghrelin, and gastrin, and the insulin receptor (INR), leptin receptor (leptin-R), cholecystokinin receptor family (for example, CCK-1R, CCK-2R), and glucagon-like peptide receptor family (for example, GLP-1R, GLP-2R) have been identified [22]. Proteolytic enzymes are mainly produced by the stomach (pepsin), pancreas (trypsin, chymotrypsin, and elastase), and intestine (membranous and cytosolic enzymes) [4]. Several studies have shown that G proteincoupled receptor (GPCR)-related mechanisms involved in the direct nutrient-sensing of proteins, lipids, and carbohydrates result in hormone secretion, while little attention has been paid to the nutrient sensing involved in the direct activation of hormone secretion in response to dietary protein restriction $[23,24]$.

To gain insight into the variations underlying the adaptive response to a protein-restricted diet in weaned pigs, we devised an experiment to evaluate the effects of dietary protein restriction on growth performance, ileal AA digestibility and the variation in serum free AAs as well as the expression levels of nutrient-sensing, hormone and receptor genes and genes encoding gastrointestinal digestive enzymes and nutrient transporters after feeding weaned pigs protein-restricted diets with three different levels of CP.

\section{RESULTS}

\section{Effect on growth performance}

As shown in Table 1, the weaned pigs fed the $14 \%$ $\mathrm{CP}$ diet had a final BW $(P<0.05), \mathrm{ADG}(P<0.05)$ and $\mathrm{F} / \mathrm{G}(P<0.05)$ that were different from those observed in the pigs fed the $17 \% \mathrm{CP}$ and $20 \% \mathrm{CP}$ diets, while ADFI was significantly different between the $14 \% \mathrm{CP}$ and $20 \%$ CP groups $(P<0.05)$.

\section{Effect on the serum concentration of free AAs and biochemical parameters}

As shown in Table 2, fed the weaned pigs the $20 \% \mathrm{CP}$ diet had a significantly different serum free AA concentrations of $\operatorname{Arg}(P<0.05)$, His $(P<0.05)$, Leu $(P<0.01)$, Val $(P<0.01)$, and $\operatorname{Tyr}(P<0.05)$ than the pigs fed the $14 \% \mathrm{CP}$ diet, while Ser $(P<0.05)$ was significantly different between the $14 \% \mathrm{CP}$ and $17 \% \mathrm{CP}$ groups. There was no significant difference $(P>0.05)$ in the serum free AA concentrations of other AAs between the three groups of weaned pigs (Table 2).

As shown in Table 2, the weaned pigs fed the $20 \%$ $\mathrm{CP}$ diet had significantly different serum biochemical parameters of $\mathrm{UN}(P<0.05)$ than the $17 \% \mathrm{CP}$ diet group, while cholesterol $(P<0.05)$ and triglycerides $(P<0.05)$ were significantly different among the $14 \% \mathrm{CP}$ and $20 \%$ 
Table 1: Protein-restricted diets affect growth performance in young weaned pigs

\begin{tabular}{|c|c|c|c|c|c|}
\hline Items & $14 \% \mathrm{CP}$ & $17 \% \mathrm{CP}$ & $20 \% \mathrm{CP}$ & $P$ value & SEM \pm \\
\hline \multicolumn{6}{|c|}{ Young weaning pigs $^{1}$} \\
\hline Initial $\mathrm{BW}^{2}, \mathrm{~kg}$ & 9.54 & 9.56 & 9.48 & 0.972 & 0.142 \\
\hline Final BW, kg & $26.21^{\mathrm{b}}$ & $29.64^{\mathrm{a}}$ & $32.23^{\mathrm{a}}$ & 0.002 & 0.799 \\
\hline $\mathrm{ADG}^{3}, \mathrm{~g} / \mathrm{d}$ & $369.50^{b}$ & $446.60^{\mathrm{a}}$ & $505.4^{\mathrm{a}}$ & 0.003 & 18.494 \\
\hline $\mathrm{ADFI}^{4}, \mathrm{~g} / \mathrm{d}$ & $691.50^{b}$ & $766.80^{\mathrm{ab}}$ & $837.60^{\mathrm{a}}$ & 0.089 & 27.570 \\
\hline$F: G^{5}$ & $1.86^{\mathrm{a}}$ & $1.71^{\mathrm{b}}$ & $1.65^{\mathrm{b}}$ & 0.003 & 0.029 \\
\hline
\end{tabular}

Data are means with the pooled means \pm standard error of the mean (SEM), $n=8 /$ treatment group. ${ }^{\text {a,b }}$ Mean values with different letters were considered to be significantly different $(P<0.05)$ from applying a one-way ANOVA followed by Duncan's multiple comparison test. ${ }^{1}$ Both the $17 \% \mathrm{CP}$ diet and the $14 \% \mathrm{CP}$ diet were supplemented with 4 essential amino acids (L-lysine, L-methionine, L-threonine, and L-tryptophan) (see Table 4) to provide the same total concentrations as in the $20 \% \mathrm{CP}$ diet. ${ }^{2} \mathrm{BW}$ : body weight; ${ }^{3} \mathrm{ADG}$ : average daily gain; ${ }^{4} \mathrm{ADFI}$ : average daily feed intake; ${ }^{5} \mathrm{~F}: \mathrm{G}$ : the ratio of feed and gain. $\mathrm{CP}=\mathrm{crude}$ protein.

Table 2: Protein-restricted diets affect serum concentrations of free amino acids (AAs) and serum biochemical parameters in young weaned pigs

\begin{tabular}{|c|c|c|c|c|c|}
\hline Items & $14 \% \mathrm{CP}$ & $17 \% \mathrm{CP}$ & $20 \% \mathrm{CP}$ & $P$ value & $\operatorname{SEM} \pm$ \\
\hline \multicolumn{6}{|l|}{ Young weaning pigs ${ }^{1}$} \\
\hline \multicolumn{6}{|c|}{ Serum free AAs concentration } \\
\hline Arg & $44.58^{\mathrm{b}}$ & $53.01^{\mathrm{ab}}$ & $58.16^{\mathrm{a}}$ & 0.036 & 3.958 \\
\hline His & $25.10^{\mathrm{b}}$ & $28.23^{\mathrm{ab}}$ & $34.17^{\mathrm{a}}$ & 0.046 & 2.66 \\
\hline Ile & 23.27 & 21.44 & 26.36 & 0.313 & 1.436 \\
\hline Leu & $32.54^{\mathrm{b}}$ & $40.25^{\mathrm{a}}$ & $44.03^{\mathrm{a}}$ & 0.003 & 3.381 \\
\hline Lys & 67.35 & 74.73 & 73.92 & 0.076 & 2.337 \\
\hline Met & 28.15 & 33.26 & 36.24 & 0.204 & 2.362 \\
\hline Phe & 20.38 & 25.13 & 27.36 & 0.105 & 2.058 \\
\hline Thr & 24.14 & 31.23 & 30.26 & 0.069 & 2.219 \\
\hline Trp & 29.73 & 28.36 & 32.63 & 0.386 & 1.259 \\
\hline Val & $29.18^{b}$ & $37.27^{\mathrm{ab}}$ & $42.37^{\mathrm{a}}$ & 0.004 & 3.84 \\
\hline Gly & 130.08 & 142.92 & 148.43 & 0.351 & 5.436 \\
\hline Ser & $28.32^{\mathrm{b}}$ & $34.37^{\mathrm{a}}$ & $31.28^{\mathrm{ab}}$ & 0.033 & 1.747 \\
\hline Glu & 50.27 & 54.46 & 58.73 & 0.203 & 2.442 \\
\hline Tyr & $20.23^{b}$ & $29.16^{\mathrm{a}}$ & $28.83^{\mathrm{a}}$ & 0.012 & 2.923 \\
\hline Asn & 25.26 & 24.12 & 31.53 & 0.202 & 2.304 \\
\hline Asp & 6.72 & 7.92 & 7.32 & 0.369 & 0.346 \\
\hline Gln & 213.37 & 242.53 & 248.23 & 0.349 & 10.796 \\
\hline Ala & 123.67 & 136.25 & 153.24 & 0.242 & 8.568 \\
\hline \multicolumn{6}{|c|}{ Serum biochemical parameters } \\
\hline Total Protein $(\mathrm{g} / \mathrm{L})$ & 61.2 & 63.6 & 59.8 & 0.341 & 1.110 \\
\hline Urea Nitrogen $(\mathrm{mmol} / \mathrm{L})$ & $2.66^{b}$ & $3.02^{\mathrm{b}}$ & $4.13^{\mathrm{a}}$ & 0.003 & 0.442 \\
\hline Glucose (mmol/L) & 5.29 & 5.64 & 6.06 & 0.301 & 0.223 \\
\hline Cholesterol (mmol/L) & $2.60^{\mathrm{a}}$ & $2.31^{\mathrm{ab}}$ & $1.98^{\mathrm{b}}$ & 0.037 & 0.179 \\
\hline Triglyceride (mmol/L) & $0.84^{\mathrm{a}}$ & $0.58^{\mathrm{ab}}$ & $0.49^{\mathrm{b}}$ & 0.015 & 0.105 \\
\hline
\end{tabular}

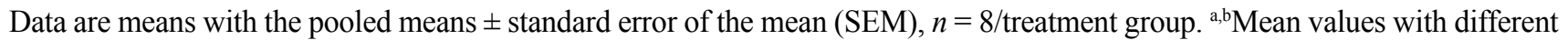
letters were considered to be significantly different $(P<0.05)$ from applying a one-way ANOVA followed by Duncan's multiple comparison test. ${ }^{1}$ Both the $17 \% \mathrm{CP}$ diet and the $14 \% \mathrm{CP}$ diet were supplemented with 4 essential amino acids (L-lysine, L-methionine, L-threonine, and L-tryptophan) (see Table 4) to provide the same total concentrations as in the $20 \%$ CP diet. 
Table 3: Protein-restricted diets affect the ileal digestibility of DE, DM, and IDAA in young weaned pigs

\begin{tabular}{|c|c|c|c|c|c|}
\hline Items & $14 \% \mathrm{CP}$ & $17 \% \mathrm{CP}$ & $20 \%$ CP & $P$ value & $\widehat{S E M} \pm$ \\
\hline \multicolumn{6}{|c|}{ Ileal digestibilities of DE, DM, and IDAA ${ }^{1}$} \\
\hline Energy & 86.58 & 84.12 & 83.64 & 0.194 & 0.901 \\
\hline $\mathrm{DM}^{2}$ & 80.30 & 82.20 & 81.30 & 0.194 & 0.910 \\
\hline $\mathrm{CP}^{3}$ & $82.3^{\mathrm{a}}$ & $81.40^{\mathrm{ab}}$ & $79.90^{\mathrm{b}}$ & 0.009 & 0.700 \\
\hline Arg & $88.52^{\mathrm{a}}$ & $86.83^{\mathrm{a}}$ & $80.64^{\mathrm{b}}$ & 0.006 & 2.400 \\
\hline His & $83.39^{\mathrm{a}}$ & $78.23^{\mathrm{b}}$ & $78.32^{\mathrm{b}}$ & 0.021 & 1.710 \\
\hline Ile & $84.78^{\mathrm{a}}$ & $82.26^{\mathrm{ab}}$ & $78.21^{\mathrm{b}}$ & 0.011 & 1.910 \\
\hline Leu & 83.89 & 80.37 & 80.89 & 0.285 & 2.090 \\
\hline Lys & $87.91^{\mathrm{a}}$ & $83.46^{\mathrm{a}}$ & $77.54^{b}$ & $<0.001$ & 3.600 \\
\hline Met & $87.73^{a}$ & $83.66^{\mathrm{ab}}$ & $80.10^{\mathrm{b}}$ & 0.043 & 1.640 \\
\hline Cys & 84.43 & 83.98 & 80.26 & 0.136 & 1.320 \\
\hline Phe & $83.91^{\mathrm{a}}$ & $81.97^{\mathrm{ab}}$ & $77.95^{\mathrm{b}}$ & 0.029 & 2.890 \\
\hline Tyr & 87.54 & 85.85 & 84.86 & 0.402 & 2.240 \\
\hline Thr & $80.57^{\mathrm{a}}$ & $77.27^{\mathrm{ab}}$ & $74.64^{b}$ & 0.031 & 3.620 \\
\hline Trp & $80.46^{\mathrm{a}}$ & $77.12^{\mathrm{ab}}$ & $73.63^{\mathrm{b}}$ & 0.007 & 1.970 \\
\hline Val & $79.36^{\mathrm{a}}$ & $72.58^{\mathrm{b}}$ & $72.28^{\mathrm{b}}$ & 0.007 & 2.310 \\
\hline Ala & 82.87 & 80.14 & 80.23 & 0.261 & 0.900 \\
\hline Asp & $80.96^{\mathrm{a}}$ & $78.52^{\mathrm{ab}}$ & $74.22^{\mathrm{b}}$ & 0.02 & 2.820 \\
\hline Glu & $87.67^{\mathrm{a}}$ & $86.68^{a}$ & $80.88^{b}$ & 0.005 & 2.120 \\
\hline Gly & 77.52 & 76.54 & 74.43 & 0.518 & 0.910 \\
\hline Pro & $76.30^{\mathrm{a}}$ & $72.47^{\mathrm{ab}}$ & $70.93^{b}$ & 0.038 & 1.600 \\
\hline Ser & $82.10^{\mathrm{a}}$ & $79.89^{\mathrm{ab}}$ & $75.72^{\mathrm{b}}$ & 0.012 & 3.640 \\
\hline
\end{tabular}

Data are means with the pooled means \pm standard error of the mean (SEM), $n=8 /$ treatment group. ${ }^{\mathrm{a}, \mathrm{b}}$ Mean values with different letters were considered to be significantly different $(P<0.05)$ from applying a one-way ANOVA followed by Duncan's multiple comparison test. ${ }^{1}$ Both the $17 \% \mathrm{CP}$ diet and the $14 \% \mathrm{CP}$ diet were supplemented with 4 essential amino acids (L-lysine, L-methionine, L-threonine, and L-tryptophan) (see Table 4) to provide the same total concentrations as in the $20 \% \mathrm{CP}$ diet. ${ }^{2} \mathrm{DM}=$ dry matter; ${ }^{3} \mathrm{CP}=$ crude protein; IDAA $=$ ileal digesta of amino acids.

$\mathrm{CP}$ diet groups. However, there was no difference in the serum parameters of total protein $(P>0.05)$ and glucose $(P>0.05)$ between the weaned pigs fed the $20 \% \mathrm{CP}$ diet and those in the $14 \% \mathrm{CP}$ and $17 \% \mathrm{CP}$ diet groups.

\section{Effect on the ileal digestibility of AAs}

As shown in Table 3, the low-CP diet had no effect $(P>0.05)$ on DE and DM. Weaned pigs fed the $14 \%$ CP diet showed higher digestibility of CP $(P<0.01)$, Arg $(P<0.01)$, His $(P<0.05)$, Ile $(P<0.05)$, Lys $(P<$ $0.001)$, Met $(P<0.05)$, Phe $(P<0.05)$, Thr $(P<0.05)$, Trp $(P<0.01)$, Val $(P<0.01)$, Asp $(P<0.05)$, Glu $(P<$ $0.01)$, Pro $(P<0.05)$, and Ser $(P<0.05)$ than pigs fed the $20 \%$ CP diet (Table 3). Lys digestibility increased $(P<0.001)$ from $77.54 \%$ in weaned pigs fed the $20 \%$ CP diet to $87.91 \%$ in weaned pigs fed the $14 \%$ CP diet. There was no significant difference $(P>0.05)$ in the digestibility of other AAs between the three groups of weaned pigs (Table 3 ).

\section{Effects on the gene expression levels of nutrient-sensing and hormone secretion genes, gastrointestinal digestive enzymes, and nutrient transporters}

As shown in Figure 1, weaned pigs fed the $20 \% \mathrm{CP}$ diet showed the highest mRNA levels of taste receptor type 1 member 1 (TasR1); however, TasR1 levels were different between the $17 \%$ and $20 \%$ CP diet groups $(P<$ $0.05)$ but not the $14 \% \mathrm{CP}$ diet group $(P>0.05)$. There was no significant difference $(P>0.05)$ in the mRNA levels of taste 1 receptor member 2 (TasR2), taste 1 receptor member 3 (TasR3), and G protein-coupled receptor, class C, group 6, member A (GPRC6A) among the three groups of weaned pigs (Figure 1A). The weaned pigs fed the 20\% $\mathrm{CP}$ diet showed the highest mRNA levels of calciumsensing receptor, transcript variant 1 (CaSR); however, there was no significant difference $(P>0.05)$ between the $14 \% \mathrm{CP}$ and the $17 \% \mathrm{CP}$ groups. There were no significant differences $(P>0.05)$ in the mRNA levels of 
long-chain fatty acid receptor G-protein-coupled receptor 40 (GPR40), short-chain fatty acid receptor G-proteincoupled receptor 41 (GPR41), and short-chain fatty acid receptor G-protein-coupled receptor 43 (GPR43) among the three groups of weaned pigs (Figure 1B).

As shown in Figure 2A and Figure 2B, there were no significant differences $(P>0.05)$ in the mRNA levels of somatostatin (SST), ghrelin, glucagon-like peptide 1 receptor (GLP-1R), glucagon-like peptide 2 receptor (GLP-2R), insulin receptor (INR), leptin receptor
(Leptin-R), gastrin, or cholecystokinin B receptor (CCK$2 \mathrm{R}$ ) between the three groups of weaned pigs. As shown in Figure 2B, the weaned pigs fed the $17 \% \mathrm{CP}$ diet showed higher mRNA levels of the cholecystokinin type A receptor (CCK-1R) than the pigs fed the 14\% CP diet $(P$ $=0.031)$; however, there was no significant difference $(P>$ 0.05 ) between the 17 and $20 \%$ CP diet groups.

As shown in Figure 3, weaned pigs fed the 17\% $\mathrm{CP}$ diet displayed higher mRNA levels of pepsinogen than pigs fed the $14 \% \mathrm{CP} \operatorname{diet}(P=0.021)$. However,
A

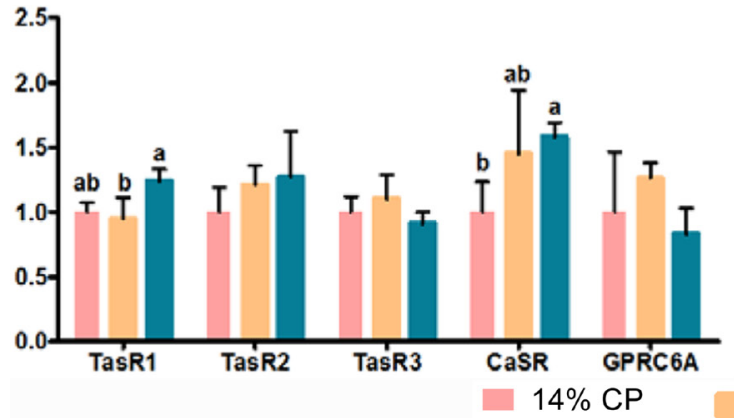

B

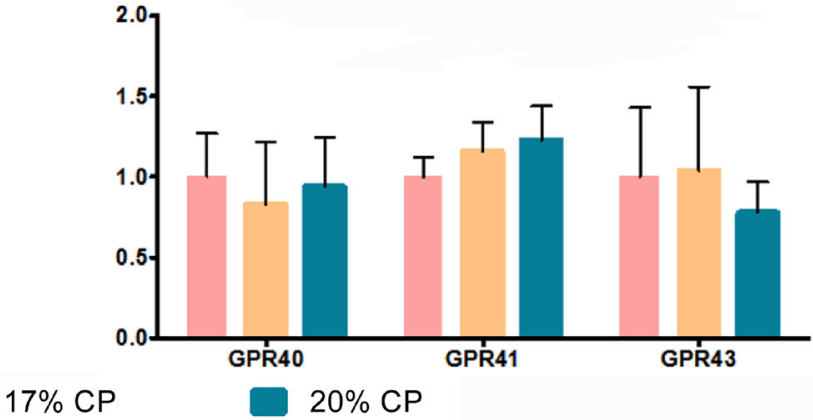

Figure 1: mRNA abundance of nutrient-sensing genes in the jejunum of young weaned pigs fed the protein-restricted diets. Both the 17\% CP diet and the 14\% CP diet were supplemented with 4 essential amino acids (L-lysine, L-methionine, L-threonine, and L-tryptophan) (see Table 4 ) to provide the same total concentrations as in the $20 \% \mathrm{CP}$ diet. $\mathrm{CP}=$ crude protein; TasR $1=$ taste receptor type 1 member 1-like; TasR2 = taste 1 receptor member 2; TasR3, taste 1 receptor member 3; CaSR = calcium-sensing receptor, transcript variant 1; GPRC6A = G protein-coupled receptor, class C, group 6, member A; GPR40 = long-chain fatty acid receptor G-protein-coupled receptor 40 (also known as free fatty acid receptor 1, FFAR1); GPR41 = short-chain fatty acid receptor G-protein-coupled receptor 41 (also known as free fatty acid receptor 3, FFAR3); GPR43 = short-chain fatty acid receptor G-protein-coupled receptor 43 (also known as free fatty acid receptor 2 , FFAR2). The data are means, with the pooled means \pm standard error of the mean (SEM), $n=8 /$ treatment group. ab Mean values with different letters were considered to be significantly different $(P<0.05)$ according to a one-way ANOVA followed by Duncan's multiple comparison test. The mRNA abundance of TasR1, TasR2, TasR3, CaSR, and GPRC6A genes were shown in (A) and the mRNA abundance of GPR40, GPR41, and GPR43 genes were shown in (B).
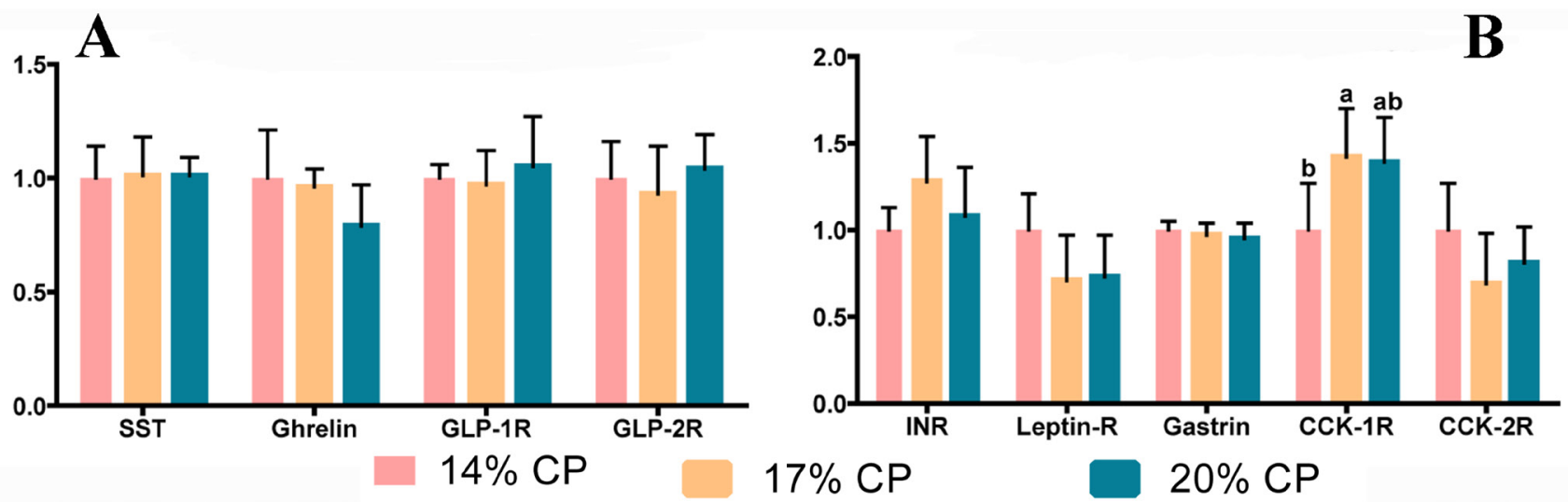

Figure 2: mRNA abundance of hormone secretion genes in the jejunum of young weaned pigs fed protein-restricted diets. Both the 17\% CP diet and the 14\% CP diet were supplemented with 4 essential amino acids (L-lysine, L-methionine, L-threonine, and L-tryptophan) (see Table 4) to provide the same total concentrations as in the $20 \% \mathrm{CP}$ diet. $\mathrm{CP}=$ crude protein; $\mathrm{SST}=$ somatostatin; GLP-1R = glucagon-like peptide 1 receptor; GLP-2R = glucagon-like peptide 2 receptor; $I N R=$ insulin receptor; Leptin- $\mathrm{R}=$ leptin receptor; $\mathrm{CCK}-1 \mathrm{R}=$ cholecystokinin type A receptor; CCK-2R = cholecystokinin B receptor. Data are means, with the pooled means \pm standard error of the mean (SEM), $n=8 /$ treatment group. ${ }^{\text {ab }}$ Mean values with different letters were considered to be significantly different $(P<0.05)$ according to a one-way ANOVA followed by Duncan's multiple comparison test. The mRNA abundance of SST, Ghrelin, GLP-1R, and GLP-2R genes were shown in (A), and the mRNA abundance of INR, Leptin-R, Gastrin, CCK-1R, and CCK-2R genes were shown in (B). 
there was no significant difference $(P>0.05)$ between the $17 \%$ and $20 \% \mathrm{CP}$ diet groups. There was no significant difference $(P>0.05)$ in the mRNA levels of trypsinogen, chymotrypsin, carboxypeptidase A (CPA), carboxypeptidase B (CPB), amino peptidase A (APA), amino peptidase B (APB), pancreatic lipase (P-lipase), sucrose, maltase, and $\alpha$-amylase between the three groups of weaned pigs (Figure 3 ).

As shown in Figure 4A, the weaned pigs fed the $20 \%$ CP diet showed higher mRNA levels of solute carrier family 1 (EAAC1) than pigs fed the $14 \% \mathrm{CP}$ and $17 \%$ $\mathrm{CP}$ diets $(P=0.038)$; however, there was no significant difference $(P>0.05)$ between the $14 \%$ and $17 \% \mathrm{CP}$ diet groups. Weaned pigs fed the $14 \% \mathrm{CP}$ diet showed a higher mRNA levels of $\mathrm{Na}^{+}$-dependent neutral amino acid exchanger 2 (ASCT2) than pigs fed the 20\% CP $\operatorname{diet}(P=0.041)$, but there was no significant difference $(P>0.05)$ between the $17 \% \mathrm{CP}$ and $20 \% \mathrm{CP}$ diet groups (Figure 4A). The dipeptide transporter1 (PepT1) levels between the weaned pigs fed the $17 \% \mathrm{CP}$ diet and the pigs fed the $14 \% \mathrm{CP}$ diet showed a significant difference $(P=$ $0.027)$, but there was no significant difference $(P>0.05)$ between the $17 \% \mathrm{CP}$ and $20 \% \mathrm{CP}$ diet groups (Figure $4 \mathrm{C}$ ). There were no significant differences $(P>0.05)$ in the
A

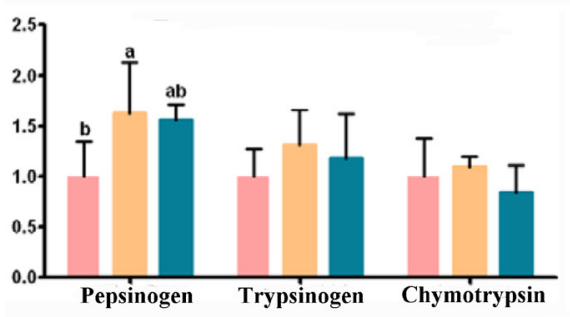

B

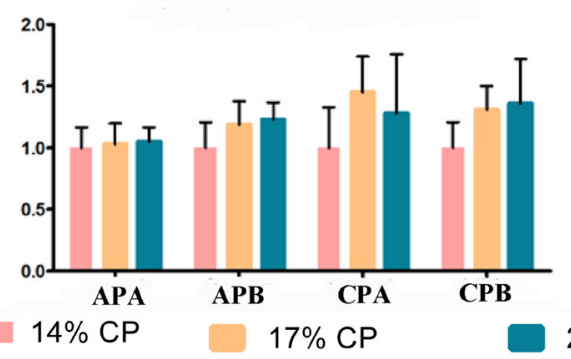

C

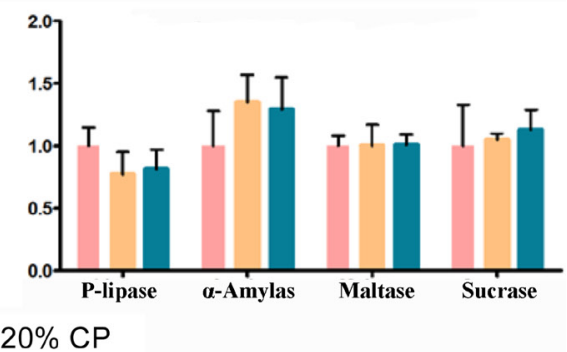

Figure 3: mRNA abundance of gastrointestinal digestive enzyme genes in the duodenum, jejunum, pancreas, and stomach of young weaned pigs fed the protein-restricted diets. Both the $17 \% \mathrm{CP}$ diet and the $14 \%$ CP diet were supplemented with 4 essential amino acids (L-lysine, L-methionine, L-threonine, and L-tryptophan) to provide the same total concentrations as in the $20 \%$ $\mathrm{CP}$ diet. $\mathrm{CP}=$ crude protein; $\mathrm{APA}=$ amino peptidase $\mathrm{A} ; \mathrm{APB}=$ amino peptidase $\mathrm{B} ; \mathrm{CPA}=$ carboxypeptidase $\mathrm{A} ; \mathrm{CPB}=$ carboxypeptidase $\mathrm{B}$; P-lipase $=$ pancreatic lipase. Data are means, with the pooled means \pm standard error of the mean (SEM), $n=8 /$ treatment group. ${ }^{\text {ab Mean }}$ values with different letters were considered to be significantly different $(P<0.05)$ according to a one-way ANOVA followed by Duncan's multiple comparison test. The mRNA abundance of Pepsinnogen, Trypsinnogen, and Chymotrypsin genes were shown in (A), the mRNA abundance of APA, APB, CPA, and CPB genes were shown in (B), and the mRNA abundance of P-lipase, $\alpha$-Amylase, Maltase, and Sucrase genes were shown in $(\mathbf{C})$.

A

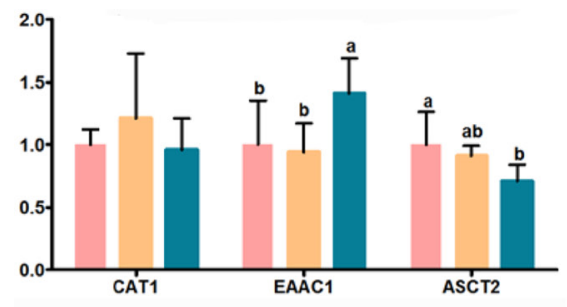

B

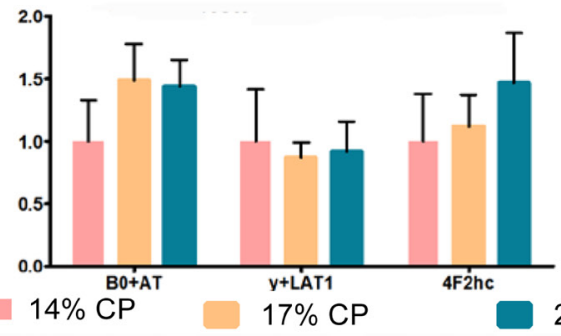

C

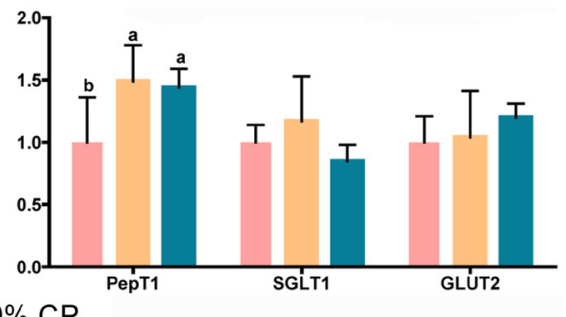

Figure 4: mRNA abundance of nutrient transporter genes in the jejunum of young weaned pigs fed the protein-restricted diets. Both the 17\% CP diet and the 14\% CP diet were supplemented with 4 essential amino acids (L-lysine, L-methionine, L-threonine, and L-tryptophan) to provide the same total concentrations as in the $20 \% \mathrm{CP}$ diet. $\mathrm{CP}=$ crude protein; CAT1 = cationic amino acid transporter 1 ; $\mathrm{EAAC} 1=$ solute carrier family 1 (neuronal/epithelial high affinity glutamate transporter, system Xag), member 1 (SLC1A1); ASCT2 = Na ${ }^{+}$ dependent neutral amino acid exchanger $2 ; \mathrm{B}^{0+} \mathrm{AT}=\mathrm{b}^{0,+}$ amino acid transporter; $\mathrm{y}^{+} \mathrm{LAT} 1=\mathrm{y}^{+} \mathrm{L}$-type amino acid transporter $1 ; 4 \mathrm{~F} 2 \mathrm{hc}=$ solute carrier family 7 member 9 (SLCA9); PepT1 = dipeptide transporter 1; SGLT1 = sodium-glucose transporter 1; GLUT2= glucose transporter 2. Data are the means with the pooled means \pm standard error of the mean (SEM), $n=8$ /treatment group. ${ }^{\text {ab }}$ Mean values with different letters were considered to be significantly different $(P<0.05)$ according to a one-way ANOVA followed by Duncan's multiple comparison test. The mRNA abundance of CAT1, EAAC1, and ASCT2 genes were shown in (A), the mRNA abundance of B0+AT, y+LAT1, and 4F2hc genes were shown in (B), and the mRNA abundance of PepT1, SGLT1, and GLUT2 genes were shown in (C). 
mRNA levels of cationic amino acid transporter1 (CAT1), $\mathrm{b}^{0,+}$ amino acid transporter $\left(\mathrm{B}^{0+} \mathrm{AT}\right), \mathrm{y}^{+} \mathrm{L}$-type amino acid transporter1 $\left(\mathrm{y}^{+} \mathrm{LAT} 1\right)$, solute carrier family 7 member 9 (4F2hc), sodium-glucose transporter 1 (SGLT1), and glucose transporter 2 (GLUT2) among the three groups of weaned pigs (Figure 4A, 4B, and 4C).

\section{DISCUSSION}

Several reports have shown that a diet containing low CP supplemented with AAs may reduce diarrhea in weaned pigs, boost feed economy, repair digestive function by increasing the digestion and absorption of nutrients (such as AAs), and reduce environmental pollution $[4,7,12-15]$. Previous studies have shown that a $\mathrm{CP}$ reduction of 2-3 points or more than 3 points can be implemented without affecting ADG or feed efficiency when diets are supplemented with AA [4, 12, 15, 31, 32]; however, these trends were not always observed in other studies [14-16]. In the present study, the results indicated that a reduction of dietary $\mathrm{CP}$ by 3 points with a concomitant addition of essential AAs supported similar growth performance and feed efficiency. However, a substantial reduction in dietary CP by 6 points had a negative impact on the growth performance of weaned pigs (Table 1). These results were consistent with previous results obtained by other researchers $[13,32,33]$.

AAs play important roles as metabolic intermediates in nutrition and immune function and boost growth performance $[9,10]$. Many studies have shown that a protein-restricted diet can regulate muscle and serum free AA concentrations in pigs [34-36]. In the present study, weaned pigs fed the $20 \%$ CP diet exhibited a significant difference in the serum free AA concentrations of Arg $(P<0.05)$, His $(P<0.05)$, Leu $(P<0.01)$, Val $(P<0.01)$, and Tyr $(P<0.05)$ compared with the concentrations in those fed the $14 \% \mathrm{CP}$ diet, while Ser $(P<0.05)$ was significantly different between the $14 \% \mathrm{CP}$ and $17 \% \mathrm{CP}$ groups (Table 2). The observed concentrations of His, Leu, and Val were not consistent with previous studies in starter pigs fed 19.2\% CP and 28.1\% CP diets [34]. A possible explanation for the discrepancies between this previous study and the present study could be that the variations in serum free AA concentrations depend on the investigated pig species, diet formulations and stages.

The variation in serum biochemical parameters depends on the external environment, dietary nutrition levels and endocrine status. Constantly altering and maintaining a dynamic balance in a relatively narrow range of characteristic concentrations is a sensitive indicator used for the assessment of nutritional and physiological status as well as the analysis of nutrient requirements [37]. Serum UN is commonly employed as an indicator of protein utilization efficiency, which reflects the status of the balance of AAs $[35,38]$. When there is redundant $\mathrm{CP}$, serum $\mathrm{UN}$ levels increase, as observed in the present work (Table 2); this excess $\mathrm{CP}$ cannot be stored in the body and is consequently degraded, with the production of urea, and excreted from the body $[35,39]$. When weaned pigs were fed the protein-restricted diets $(17 \% \mathrm{CP}$ or $14 \% \mathrm{CP}$ diets in our study), they exhibited a lower serum UN concentration $(P<0.05$, Table 2$)$, and these results were consistent with the results of previous studies [4, 7, 32, 35, 39]. These findings suggest that pigs in different stages exhibit either an increased $\mathrm{N}$ efficiency or decreased protein breakdown, which ultimately reduces $\mathrm{N}$ excretion and protects the surrounding environment [4, 6, 35]. Variations in serum cholesterol and triglyceride contents are a sensitive indicator of lipid metabolism and nutrition status in pigs and humans [35]. In the present study, the weaned pigs fed the $20 \%$ CP diet and those fed the $14 \%$ $\mathrm{CP}$ diet exhibited a significant difference in the serum biochemical parameters of cholesterol $(P<0.05)$ and the level of triglycerides $(P<0.05)$ (Table 2$)$. These results are consistent with a previous hypothesis proposed by other researchers that an excess low-protein diet or AA imbalance may cause high cholesterol and triglyceride concentrations in serum as well as increased fat content in the entire body [35]. This could be supported by the increasing trend in serum cholesterol and triglyceride levels observed in our study in pigs receiving the protein-restricted diets similar results have been reported elsewhere [35, 40-44]. Subsequent experiments also confirmed that an excessively CP-restricted diet and serious AA imbalance lead to a decrease in protein synthesis, with the remaining energy being transferred to fat deposition in broiler chickens and pigs [35, 45, 46].

A reduction of dietary $\mathrm{CP}$ by 6 points led to the highest ileal digestibility of $\mathrm{CP}$ and AAs in the present work (Table 3 ). These results were also consistent with previous findings $[4,47]$. It is possible that the different responses to the dietary $\mathrm{CP}$ levels fed to the weaned pigs in terms of the ileal digestibility of CP and AAs is due to relative increases in the rate of protein digestion and the absorption of the resulting products in the GIT. However, when dietary $\mathrm{CP}$ was reduced by 6 points and the diet was supplemented with essential AAs, the growth performance and feed efficiency of the weaned pigs could not be maintained, even when the ileal digestibility of AAs was improved. Therefore, our findings support the possibility that the nutritional requirements of pigs can be met when dietary $\mathrm{CP}$ is reduced by 3 points if the diet is supplemented with adequate amounts of essential AAs.

The umami taste receptor, composed of TasR1 + TasR3, can recognize and respond to a diverse repertoire of chemical entities, including sugars, AAs, and other nutrients [48]. The released of gut hormones involved in the control of food intake is dependent on the acute 
nutritional status of the body, suggesting that nutrient sensing mechanisms are involved in the control of their release [49]. The nutrient sensing of CaSR is expressed in a number of tissues and is involved in calcium homeostasis and the regulation of a variety of cellular processes, including proliferation, differentiation, expression, ion channel function and hormone secretion, as well as fluid absorption [23]. CCK can stimulate gallbladder contraction and pancreatic growth [50], and L-phenylalanine L-tryptophan can stimulate the release of CCK from isolated CCK cells [51]. The diets AAs with higher affinity for CaSR are the aromatic AAs L-tryptophan, L-phenylalanine, L-tyrosine and L-histidine, where basic and branch-chain AAs are the least effective [52]. Administration of L-phenylalanine elevated plasma levels of CCK and reduced food intake in human [53]. AAs also affected the release of INR via the CaR in isolated rat intestinal loop [54]. A previous study also showed dietary CP levels also affect GI hormones sensing and regulation of a variety of nutrient sensing gene expression in rat [55]. There was a significant difference between the $17 \%$ and $20 \% \mathrm{CP}$ diet groups $(P<0.05)$ but not the $14 \% \mathrm{CP}$ diet group $(P>0.05)$ in the mRNA levels of TasR1 (Figure 2) and a significant difference in the CaSR level (Figure 2) in the jejunum between the $14 \%$ and $20 \% \mathrm{CP}$ diet groups $(P<0.05)$. However, the weaned pigs fed the $17 \% \mathrm{CP}$ diet showed higher mRNA levels of CCK-1R than pigs fed the $14 \% \mathrm{CP} \operatorname{diet}(P=0.031)$ (Figure 2$)$. Studies have linked TasR1, CaSR, and CCK, demonstrating that knockdown of TasR1 in STC-1 cells (an immortalized intestinal enteroendocrine cell line) attenuates the stimulatory effects of L-phenylalanine, L-leucine and L-glutamate on CCK release [56] and that some AAs stimulate CCK release through the CaSR receptor [51]. Therefore, our results showed that the expression of nutrient-sensing genes in the jejunum can be regulated in response to a protein-restricted diet.

Several reports on pigs have shown that the levels of the main digestive enzymes are dependent on different dietary formulations and determined how effectively a given dietary formulation may enhance body growth $[57,58]$. The digestion of dietary proteins and other nutrients in pigs is accomplished by many different parts of the GIT and results in a hydrolysated protein mixture of oligopeptides and free AAs as well as glucose $[4,23]$. A previous study showed that low-protein diets can increase the digestibility of energy and AA [4, 59]. In the present study, weaned pigs fed the $17 \% \mathrm{CP}$ diet displayed higher mRNA levels of pepsinogen than pigs fed the $14 \% \mathrm{CP} \operatorname{diet}(P=0.021)$. There was no significant difference $(P>0.05)$ between the $17 \%$ and $20 \% \mathrm{CP}$ diet groups (Figure 3). This result is consistent with previous results showing that a protein-restricted diet can affect the expression of chymotrypsin, aminopeptidase, amylase, and carboxypeptidase [50,60]; however, it is not consistent with previous results indicating that a proteinrestricted diet cannot affect the expression of pepsinogen and trypsinogen in pigs $[4,50,60]$. Therefore, in the present study, the $17 \% \mathrm{CP}$-restricted diet can increase the expression of genes encoding pepsinogen in the stomach but induced a trend toward higher mRNA levels of trypsinogen, chymotrypsin, CPA, and $\alpha$-amylase than those in other groups, although there were no significant differences. A possible explanation for the different responses of digestive enzymes to the protein-restricted diet is the complex regulation at both the transcriptional and translational levels by a variety of factors, including the composition and balance of dietary AA and GIT health status. Future studies are needed to determine the protein abundances of digestive enzymes in pigs fed a proteinrestricted diet or an adequate $\mathrm{CP}$ diet.

The transport of AAs in the intestines is critical for the supply of AAs to all tissues and the homeostasis of plasma AA levels, and the intracellular presence of available AAs is regulated by many different kinds of AA transporters $[6,9,10,61]$. In different cell types, all types of AA transporters are ubiquitously localized in membranes. These transporters sense AA availability, relay nutrient signals (including AAs) to the cell interior, regulate the uptake and efflux of AAs and trigger a series of cascade responses, which ultimately provides dual transporter and receptor functions in response to nutrient stimulation. In the present study, pigs fed the $20 \% \mathrm{CP}$ diet showed higher mRNA levels of EAAC1 than pigs fed the 14\% CP and 17\% CP diets; however, there was no significant difference $(P>0.05)$ between the $14 \%$ and $17 \%$ CP diet groups (Figure 4A). Likewise, pigs fed the $14 \%$ CP diet showed higher mRNA levels of ASCT2 than pigs fed the $20 \% \mathrm{CP}$ diet $(P=0.041)$ (Figure 4A), but there was no significant difference $(P>0.05)$ between the $17 \% \mathrm{CP}$ and 20\% CP diet groups (Figure 4A). Notably, there was no significant difference in the mRNA levels of PepT1 $(P>0.05)$ between the $17 \% \mathrm{CP}$ and $20 \% \mathrm{CP}$ diet groups (Figure 4C). A previous report showed that reducing the dietary $\mathrm{CP}$ content increased the levels of AA transporters (EAAC1 and ASCT2) in weaned pigs [6] and demonstrated that the supplementation of a reducedCP diet with branched-chain AAs increased the levels of the AA transporter PepT1 in growing pigs fed a 17.1\% CP diet compared with those in pigs fed a $20.9 \%$ CP diet [62]. A possible explanation for the discrepancies between this previous study and the present study could be that the mRNA levels of transporters depend on the investigated pig species, diet formulations and stages. 


\section{CONCLUSIONS}

In conclusion, our findings confirmed that weaned pigs chronically fed a moderately protein-restricted diet $(17 \% \mathrm{CP})$ could catch up in terms of growth performance and feed efficiency. The provision of $20 \%$ dietary CP was beneficial to nutrient-sensing and nutrient transporter gene expression in the GIT, and the provision of $17 \%$ dietary CP was beneficial to lipid metabolism and the digestion of nutrient substances in the GIT. These findings may provide new insight for the application of nutritional strategies in the pig industry or even for human health. Further research is needed to confirm how a protein-restricted dietary regulates the complicated relationships from nutrient sensing, digestion, and absorption in pig nutrition.

\section{MATERIALS AND METHODS}

\section{Ethics statement}

All procedures involving animal subjects were approved by the Animal Welfare Committee of the Institute of Subtropical Agriculture at the Chinese Academy of Sciences (Changsha, Hunan Province, China, No.: 20160711).

\section{Experimental design and procedure}

Twenty-four cross-bred pigs [Yorkshire $\times($ Duroc $\times$ Landrace)] (Hunan Zhenghong Co., Ltd., Hunan Province, China) (initial body weight (BW), $9.57 \pm 0.64 \mathrm{~kg}$ ) were assigned randomly to one of three diet treatments ( 8 pigs/ group), corresponding to a $14 \%, 17 \%$, or $20 \%$ dietary intake of CP. All of the pigs were housed individually in metabolic cages and had free access to feedstuff and drinking water. The temperature in the metabolism room was maintained at approximately $24^{\circ} \mathrm{C}$ with constant lighting. Titanium dioxide $\left(\mathrm{TiQ}_{2}\right)(1 \mathrm{~g} / \mathrm{kg}$ diet $)$ was added to all of the experimental diets and served as a marker of indigestion to calculate total tract $\mathrm{N}$ digestibility [25]. The experimental design and procedure are shown in Figure 5. The dietary treatments of $14 \% \mathrm{CP}$ and $17 \% \mathrm{CP}$ diets were supplemented with L-Lys, L-Met, L-Thr, and L-Trp to meet the National Research Council (NRC) nutrient requirements for weaned pigs [26]. There was a 3-day acclimatization period prior to the commencement of each experiment. The experiments lasted 45 days. The ingredients and nutrient compositions of the experimental diets are shown in Table 4. Parameters related to BW and feed consumption, such as the ADG, average daily feed intake (ADFI), and ratio of feed to gain (F: G), were recorded at the beginning and end of the experimental period.

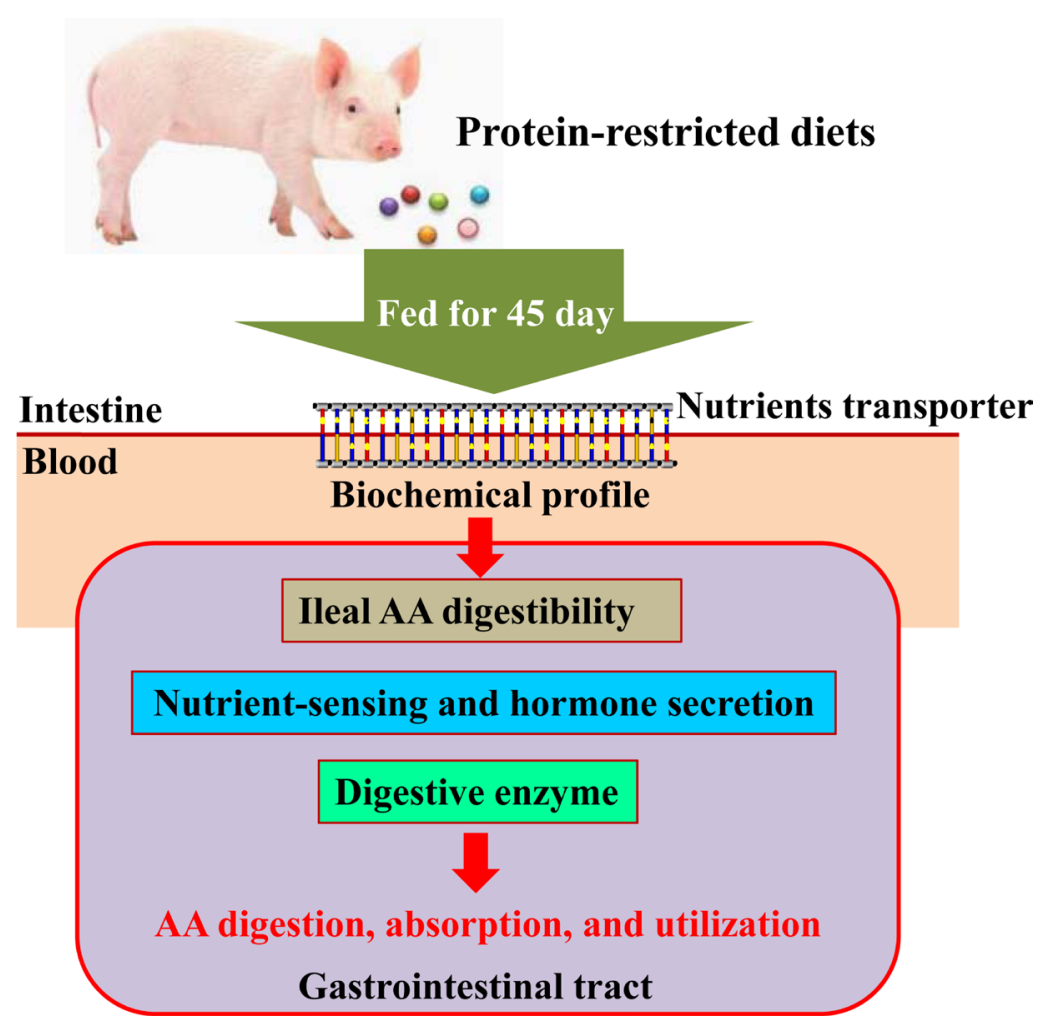

Figure 5: Experimental design. The experiments involved 24 [Yorkshire $\times$ (Duroc $\times$ Landrace)] young weaned pigs. Both the 17\% $\mathrm{CP}$ diet and the 14\% CP diet were supplemented with 4 essential amino acids (L-lysine, L-methionine, L-threonine, and L-tryptophan) to provide the same total concentrations as in the $20 \% \mathrm{CP}$ diet. $\mathrm{CP}=$ crude protein. 
Table 4: Feedstuff ingredients and nutrient composition in experimental diets for young weaned pigs (\%).

\begin{tabular}{|c|c|c|c|}
\hline \multirow{2}{*}{ Feed ingredient } & \multicolumn{3}{|c|}{ CP levels ${ }^{\mathrm{a}}$} \\
\hline & $14 \% \mathrm{CP}$ & $17 \% \mathrm{CP}$ & $20 \% \mathrm{CP}$ \\
\hline Corn $(43 \% \mathrm{CP})$ & 71.80 & 66.50 & 63.70 \\
\hline Soybean meal & 13.40 & 18.80 & 19.80 \\
\hline Whey powder & 4.40 & 4.30 & 4.30 \\
\hline Fish meal $(64 \% \mathrm{CP})$ & 1.50 & 4.00 & 9.00 \\
\hline Soybean oil & 4.10 & 2.60 & 0.80 \\
\hline Lysine hydrochloride & 0.88 & 0.62 & 0.38 \\
\hline Hydroxy methionine & 0.27 & 0.19 & 0.10 \\
\hline L-threonine & 0.33 & 0.21 & 0.09 \\
\hline L-tryptophan & 0.08 & 0.04 & 0.01 \\
\hline $\mathrm{CaHPO}_{3}$ & 1.15 & 0.74 & 0.00 \\
\hline Rock-powder & 0.79 & 0.70 & 0.52 \\
\hline Salt & 0.30 & 0.30 & 0.30 \\
\hline $1 \%$ Premix $^{b}$ & 1.00 & 1.00 & 1.00 \\
\hline Total & 100.00 & 100.00 & 100.00 \\
\hline \multicolumn{4}{|c|}{ Calculated and analyzed nutrient composition ${ }^{c}$} \\
\hline $\mathrm{DE}(\mathrm{MJ} / \mathrm{kg})$ & 14.60 & 14.60 & 14.60 \\
\hline $\mathrm{CP}$ & 14.14 & 17.32 & 20.27 \\
\hline Total Ca & 0.70 & 0.71 & 0.69 \\
\hline Total P & 0.53 & 0.55 & 0.57 \\
\hline Starch & 45.16 & 41.95 & 40.22 \\
\hline NDF & 8.40 & 8.66 & 8.54 \\
\hline $\mathrm{ADF}$ & 3.05 & 3.30 & 3.29 \\
\hline Lys & 1.26 & 1.25 & 1.26 \\
\hline Met + Cys & 0.63 & 0.65 & 0.62 \\
\hline Thr & 0.76 & 0.75 & 0.76 \\
\hline $\operatorname{Trp}$ & 0.20 & 0.20 & 0.20 \\
\hline Arg & 0.71 & 0.93 & 1.09 \\
\hline His & 0.30 & 0.37 & 0.44 \\
\hline Ile & 0.46 & 0.60 & 0.71 \\
\hline Leu & 1.11 & 1.32 & 1.52 \\
\hline Phe & 0.56 & 0.70 & 0.81 \\
\hline Val & 0.54 & 0.64 & 0.72 \\
\hline
\end{tabular}

${ }^{a}$ Diet treatment: Crude protein (CP) levels contain $14 \%, 17 \%$ and $20 \%$, respectively and supplementation with appropriate crystalline AA. ${ }^{b}$ Premix provided these amounts of vitamins and minerals per kilogram on an as-fed basis: vitamin A, 10,800 $\mathrm{IU}$; vitamin $\mathrm{D}_{3}, 4,000 \mathrm{IU}$; vitamin $\mathrm{E}$, $40 \mathrm{IU}$; vitamin $\mathrm{K}_{3}, 4 \mathrm{mg}$; vitamin $\mathrm{B}_{1}, 6 \mathrm{mg}$; vitamin $\mathrm{B}_{2}, 12 \mathrm{mg}$; vitamin $\mathrm{B}_{6}, 6 \mathrm{mg}$; vitamin $\mathrm{B}_{12}, 0.05 \mathrm{mg}$; biotin, $0.2 \mathrm{mg}$; folic acid, $2 \mathrm{mg}$; niacin, $50 \mathrm{mg}$; D-calcium pantothenate, $25 \mathrm{mg}$; $\mathrm{Fe}, 100 \mathrm{mg}$ as ferrous sulfate; $\mathrm{Cu}, 150 \mathrm{mg}$ as copper sulphate; $\mathrm{Mn}, 40 \mathrm{mg}$ as manganese oxide; $\mathrm{Zn}, 100 \mathrm{mg}$ as zinc oxide; I, $0.5 \mathrm{mg}$ as potassium iodide; and Se, $0.3 \mathrm{mg}$ as sodium selenite. The values are expressed as percentage (\%), except for digestible energy (DE; $\mathrm{MJ} / \mathrm{kg}$ ), essential amino acid (EAA)/nonessential amino acid (NEAA). ${ }^{\circ}$ The DE was calculated according to NRC (2012). ${ }^{\mathrm{C}}$ All other values represent analyzed values. 
Table 5: Primers used for relative quantitative PCR analysis

\begin{tabular}{|c|c|c|c|c|}
\hline Gene & 5'-Primer (F) & 3'-Primer (R) & Length (bp) & Accession No. \\
\hline \multicolumn{5}{|l|}{ Nutrient-sensing gene } \\
\hline TasR $1^{1}$ & TCCCTGGGCTTCATACTGG & TTCTCTGGCAAGTCCTTACCC & 92 & XM_003356140.1 \\
\hline TasR2 $^{2}$ & TGTATCACGGTGCGCTCTTT & TGGTGTTGATCAGCAGTCCC & 259 & NM_001267894.1 \\
\hline TasR $^{3}$ & GTAGGGTAGAGGCCCACTCA & ACTTTCAGAGGTTGGGGTGC & 335 & NM_001113288.1 \\
\hline $\mathrm{GPRC} \mathrm{A}^{4}$ & CTTGAGAAAATCATAGCAGAAGCC & GGAATGGTAGTTATCTTGGTGGC & 161 & XM_003480266.1 \\
\hline $\mathrm{CaSR}^{5}$ & GGGACCAGGAAAGGAATCAT & CACGGCAAAGAGGGTGAGT & 219 & XM_003132642.1 \\
\hline GPR40/FFAR $1^{6}$ & TGCTCTGACCTCCTGCTGG & CACACACCCCCCAGGAATAG & 89 & XM_003127043.1 \\
\hline${\text { GPR } 41 / \text { FFAR }^{7}}^{7}$ & GCTGCTGTTCCTGCCTTTC & TGAAGAAGATGAATCCAGAGAGTG & 98 & NM_005304.3 \\
\hline GPR43/FFAR2 ${ }^{8}$ & CCCATCCACATCCTCCTGC & GCTGCTGTAGAAGCCGAAAC & 150 & XM_003127046.1 \\
\hline \multicolumn{5}{|l|}{ Hormone secretion gene } \\
\hline SST $^{9}$ & GCTGGGAAGCAGGTAAGGAG & GAACTGTGACCTACTGCGCT & 238 & AY596204.1 \\
\hline Ghrelin & GAAGGCACGGAGGACAAGC & GCTGGTCTCAGGGACAATCAC & 398 & NM_213807.1 \\
\hline Gastrin & AAAGAGCCACATGAGCTGGAT & GGTTCTAGGGACGCTGGTCT & 120 & NM_001004036 \\
\hline INR $^{10}$ & GGCATGGTGTACGAGGGAAA & AGGCCTCGTTGAGAAACTCG & 124 & XM_005654749.2 \\
\hline Leptin- $\mathrm{R}^{11}$ & CAGTGACATTTGGCCCTCTT & AGGCCTGGGTTTCTATCTCC & 396 & NM_001024587.1 \\
\hline $\mathrm{CCK}-1 \mathrm{R}^{12}$ & GTGGTCCACAGCCTTCTTAT & TCATTTTCGATCCCCAGTT & 68 & DQ496228 \\
\hline $\mathrm{CCK}-2 \mathrm{R}^{13}$ & GCGGCGATCTTTCTGATGAG & GCAGGAAGGCGTTGGTGA & 97 & AY322551 \\
\hline GLP-1R ${ }^{14}$ & TACTTCTGGCTGCTGGTGGAG & ACCCCAGCCTATGCTCAGGTA & 105 & NM_001256594.1 \\
\hline GLP-2R $\mathrm{R}^{15}$ & TGTCCTACGTGTCGGAGATGTC & TAATTGGCGCCCACGAA & 76 & NM_001246266.1 \\
\hline \multicolumn{5}{|c|}{ Gastrointestinal digestive enzyme gene } \\
\hline Pepsinogen & CATGGACGGAGAGACCATCG & GCCCTGTCAAAGACGGTGTA & 354 & NM_213873.2 \\
\hline Trypsinogen & GTCTGCTGCTCACTGCTACA & GCCAGAGATGAGACACTCGG & 253 & LOC 100302368 \\
\hline Chymotrypsin & GTACCTCAGCGGTGACACAT & AAGTCCGGGAGTTGCTGATG & 101 & NM_001244379.1 \\
\hline Carboxypeptidase A & TGGGGGCTGCTGATTTTTAGT & CAGATAGCCGGACGGTTGTT & 515 & NM_214244.1 \\
\hline Carboxypeptidase B & GGCTGCCGTGAAAGAACTTG & TGGCCAGCATTGTTTCCTCA & 218 & NM_214169.1 \\
\hline Amino peptidase A & ACACGGGGACAGTGAACATC & TCAGGTGGTAGAGACCCTCG & 222 & NM_214017.1 \\
\hline Amino peptidase $\mathrm{N}$ & GCTGTTGCCTGATTCCTACTTC & CTACCAGCTCAGTCCTGTCG & 230 & NM_214277.1 \\
\hline Pancreatic lipase & GGCTCCCGAACTGGATACAC & GATCCAGCCCTGTGATTCGT & 205 & NM_001177912.2 \\
\hline Sucrase & AAGTGGGAGGTGGGAACTCT & GCGTTAACTGCACAGGGTTG & 166 & XM_005657098.1 \\
\hline Maltase & AGAGTATCCTCACCGGGCAT & CAAATGACCGTCCAGCTCCT & 154 & XM_005657730.2 \\
\hline$\alpha$-Amylase & ACTCCCGAGATAGAGAAAGTGTT & GACTGGGTTTGTGGGGCATA & 241 & XM_005663622.2 \\
\hline \multicolumn{5}{|l|}{ Nutrients transporter gene } \\
\hline $\mathrm{ASCT} 2^{16}$ & GCTTCCGAGAGCCAAGAACT & TCCTTAACGCCTGGAAGCTG & 152 & XM_003127238.3 \\
\hline $\mathrm{EAAC}^{17}$ & GCTTCCTTCTTCCAGGGTCC & CTGGCCAATGTGGCTTGTTC & 148 & NM_001164649.1 \\
\hline $\mathrm{B}^{0+} \mathrm{AT}^{18}$ & GAGAGGTTTGGTCTTACTGCG & GCTATGACCAAGACGGAGCG & 96 & XM_003353809.2 \\
\hline $\mathrm{y}^{+} \mathrm{LAT} 1^{19}$ & TTTGTCTGACCGGCTCTTCC & GAGATCTCCTGCTGTCCTGG & 286 & XM_005666262.1 \\
\hline $4 \mathrm{~F} 2 \mathrm{hc}^{20}$ & CTCGAACCCACCAAGGAC & GAGGTGAGACGGCACAGAG & 174 & NM_001110171.1 \\
\hline $\begin{array}{l}\text { PepT1 }{ }^{21} \\
\text { SGLT1 }^{22}\end{array}$ & $\begin{array}{l}\text { CATCGCCATACCCTTCTG } \\
\text { TGTTATACCCCGAGGGCTGA }\end{array}$ & $\begin{array}{l}\text { TTCCCATCCATCGTGACATT } \\
\text { CGCAATCCATTGGGCATGAG }\end{array}$ & $\begin{array}{l}143 \\
374\end{array}$ & $\begin{array}{l}\text { NM_214347.1 } \\
\text { NM }-001164021\end{array}$ \\
\hline GLUT2 ${ }^{23}$ & TCATGTCGGTGGGACTTGTG & GGCCTGGCCCAATTTCAAAG & 105 & NM- 001164021 \\
\hline $\mathrm{CAT}^{24}$ & GCTGTCATGGCCTTCCTCTT & CTGGTACACCATGTTCGGCT & 138 & NM_001012613.1 \\
\hline $\begin{array}{l}\text { Housekeeping gene } \\
\beta \text {-actin }\end{array}$ & GGATGCAGAAGGAGATCACG & ATCTGCTGGAAGGTGGACAG & 130 & DQ845171 \\
\hline \multicolumn{5}{|c|}{ 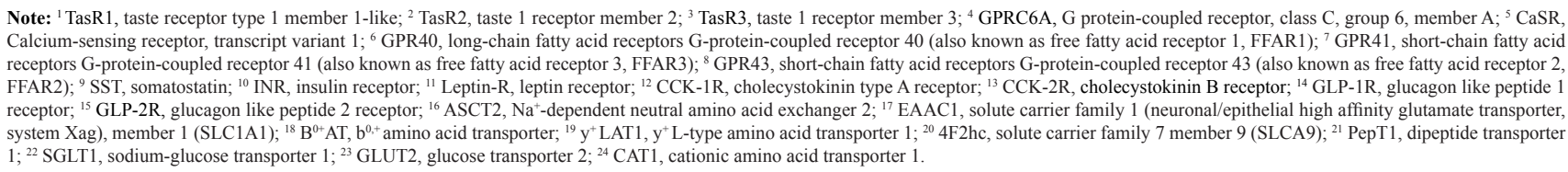 } \\
\hline
\end{tabular}

\section{Samples of blood, tissue section, and digesta collection}

All pigs were fasted overnight (for approximately $12 \mathrm{~h}$ ), and the pigs were euthanized through intravenous injection of $50 \mathrm{mg} / \mathrm{kg}$ sodium pentobarbital and then sacrificed. The blood $(5 \mathrm{~mL})$ from the overnight fasting pigs was collected by vein puncture, centrifuged at $3,000 \mathrm{~g}$ for $15 \mathrm{~min}$ at $4^{\circ} \mathrm{C}$, and immediately stored at $-80^{\circ} \mathrm{C}$ for further analysis. The collection period was divided into different intervals to conduct experiments on apparent digestibility and $\mathrm{N}$ balance (days $3-7$ ).

The $3 \mathrm{~g}$ tissue samples were collected from the midpoint of each section (i.e., the intestine (duodenum and jejunum), stomach, and pancreas) and immediately frozen in liquid nitrogen at $-80^{\circ} \mathrm{C}$ for subsequent analysis of gene expression levels as previously described $[9,10]$.
Samples of digesta were collected from the ileum to analyze the digestibility of energy (DE), dry matter (DM), $\mathrm{CP}$, and AAs as previously described [4, 27].

\section{Analysis of serum biochemical parameters and the free AA profile}

Serum biochemical parameters, including total protein, urea nitrogen (UN), glucose, cholesterol, and triglycerides, were measured using commercial kits according to the manufacturer's instructions (SinoGerman Beijing Leadman Biotech Ltd., Beijing China) on a Biochemical Analytical Instrument (Beckman Chemistry Analyzer; Beckman Coulter, Inc., Brea, CA).

The contents of 18 free AAs in serum were determined via LC-MS/MS (HPLC Ultimate 3000 and 3200 QTRAP LC-MS/MS) as described previously [9, 10, 27, 28]. 


\section{Chemical analysis}

All samples of ileal digesta were pooled and homogenized in a blender, sub-sampled, freeze-dried, and finely ground in a grinder and thoroughly mixed for analysis as previously described [4]. All of the ileal digesta samples and the three diets were analyzed for conventional parameters, such as DM, DE, and $\mathrm{N}$ and the concentrations of AAs. DM was analyzed using the AOAC protocol (1990; method 925.09) [29], and gross energy (GE) was analyzed using an oxygen bomb calorimeter as previously described. $\mathrm{N}$ was analyzed via a previously described method [4, 29]. Samples for ileal AA determination were prepared via acid hydrolysis using a previously described protocol $[4,29]$. Tryptophan was not analyzed because it was destroyed during preparation via acid hydrolysis [30].

\section{Relative quantification of the mRNA expression levels of nutrient-sensing and hormone secretion genes, gastrointestinal digestive enzymes, and nutrient transporters}

The software program Primer 5.0 (Primer-E Ltd., Plymouth, UK) was used to design the primers, which are listed in Table 5 . The $\beta$-actin housekeeping gene was employed as an internal control to normalize the expression of target gene transcripts.

Total tissue RNA was isolated using the TRIzol reagent (Invitrogen, Carlsbad, CA, USA) as previously described $[9,10]$. cDNA was then reverse transcribed and amplified via quantitative real-time PCR using an ABI 7900 PCR system (ABI Biotechnology, Eldersburg, MD, USA) as previously described $[9,10]$. Each sample had a total volume of a $10 \mu \mathrm{L}$, including $1 \mu \mathrm{L}$ of $4 \mathrm{x}$-diluted cDNA, $5 \mu \mathrm{L}$ of SYBR Green mix, $0.2 \mu \mathrm{L}$ of ROX reference dye (50 times), and $0.2 \mu \mathrm{L}$ of each of forward and reverse primer. We used the following protocol: (i) pre-denaturation $\left(10 \mathrm{~s}\right.$ at $\left.95^{\circ} \mathrm{C}\right)$; (ii) amplification and quantification for 40 cycles $\left(5 \mathrm{~s}\right.$ at $95^{\circ} \mathrm{C}, 20 \mathrm{~s}$ at $60^{\circ} \mathrm{C}$ ); (iii) melting curve analysis $\left(60-99^{\circ} \mathrm{C}\right.$, at a heating rate of $0.1^{\circ} \mathrm{C} \mathrm{s}^{-1}$, with fluorescence measurements). The mRNA expression levels of target genes, in arbitrary units, were determined from the real-time PCR threshold cycle $(\mathrm{Ct})$ in relation to $\beta$-actin, using the comparative $\mathrm{Ct}$, via the $2^{-\Delta \Delta \mathrm{Ct}}$ method [9-11].

\section{Statistical analysis}

The data were tested via ANOVA using the SAS 8.2 software program (Version 8.2; SAS Inst. Inc., Cary, NC), followed by Duncan's multiple comparison test with the pen as the experimental unit. The data obtained from mRNA measurements were also analyzed through multifactor ANOVA and the GLM procedure was used to assess the effects of different diets. The results were presented as the mean \pm standard error of the mean (SEM).
Differences between significant means were considered significantly different at $P<0.05$. The results of statistical analyses were introduced and mapped with GraphPad Prism 6.0 software (GraphPad Software, Inc.).

\section{Abbreviations}

GIT: gastrointestinal tract; AA: amino acid; CP: crude protein; ADG: average daily gain; ADFI: average daily feed intake; F: G: ratio of feed to gain; $\mathrm{TiQ}_{2}$ : titanium dioxide; $\mathrm{BW}$ : body weight; DM: dry matter; $\mathrm{DE}$ : digestibility of energy; $\mathrm{N}$ : nitrogen; GE: gross energy; SEM: standard error of the mean; GPRC6A: $\mathrm{G}$ protein-coupled receptor class $\mathrm{C}$ group 6 member A; CCK: cholecystokinin; UN: urea nitrogen; TasR1: taste receptor type 1 member 1; TasR2: taste 1 receptor member 2; TasR3: taste 1 receptor member 3; GPRC6A: $\mathrm{G}$ protein-coupled receptor, class $\mathrm{C}$, group 6 , member A; CaSR: calcium-sensing receptor, transcript variant 1; GPR40: long-chain fatty acid receptor G-proteincoupled receptor 40; GPR41: short-chain fatty acid receptor G-protein-coupled receptor 41; GPR43: shortchain fatty acid receptor G-protein-coupled receptor 43; SST: somatostatin; GLP-1R: glucagon-like peptide 1 receptor; GLP-2R: glucagon-like peptide 2 receptor; INR: insulin receptor; Leptin-R, leptin receptor; CCK-2R: cholecystokinin B receptor; CCK-1R: cholecystokinin type A receptor; CPA: carboxypeptidase A; CPB: carboxypeptidase B; APA: amino peptidase A; APB: amino peptidase B; P-lipase: pancreatic lipase; EAAC1: solute carrier family 1; ASCT2: $\mathrm{Na}^{+}$-dependent neutral amino acid exchanger 2; PepT1: dipeptide transporter 1; CAT1: cationic amino acid transporter 1; $\mathrm{B}^{0+} \mathrm{AT}: \mathrm{b}^{0,+}$ amino acid transporter; $\mathrm{y}^{+}$LAT1: $\mathrm{y}^{+}$L-type amino acid transporter 1; 4F2hc: solute carrier family 7 member 9; SGLT1: sodium-glucose transporter 1; GLUT2: glucose transporter 2 .

\section{CONFLICTS OF INTEREST}

No potential conflicts of interest was reported by the authors.

\section{FUNDING}

This research was supported by the National Basic Research Program (973) of China (No. 2013CB127301), the National Natural Science Foundation of China (No. 31402088), and the Youth Innovation Team Project of ISA, CAS (2017QNCXTD_TBE).

\section{REFERENCES}

1. Deng D, Yao K, Chu W, Li T, Huang R, Yin Y, Liu Z, Zhang $\mathrm{J}, \mathrm{Wu}$ G. Impaired translation initiation activation 
and reduced protein synthesis in weaned piglets fed a lowprotein diet. The Journal of nutritional biochemistry. 2009; 20:544-52.

2. Andriamihaja M, Davila AM, Eklou-Lawson M, Petit N, Delpal S, Allek F, Blais A, Delteil C, Tomé D, Blachier F. Colon luminal content and epithelial cell morphology are markedly modified in rats fed with a high-protein diet. American Journal of Physiology-Gastrointestinal and Liver Physiology. 2010; 299:G1030-G7.

3. Zoppi G, Gerosa F, Pezzini A, Bassani N, Rizzotti P, Bellini P, Todeschini G, Zamboni G, Vazzoler G, Tridente G. Immunocompetence and dietary protein intake in early infancy. Journal of pediatric gastroenterology and nutrition. $1982 ; 1: 175-82$.

4. He L, Wu L, Xu Z, Li T, Yao K, Cui Z, Yin Y, Wu G. Lowprotein diets affect ileal amino acid digestibility and gene expression of digestive enzymes in growing and finishing pigs. Amino Acids. 2016; 48:21-30. https://doi.org/10.1007/ s00726-015-2059-1.

5. Wright M, Sotres-Alvarez D, Mendez MA, Adair L. The association of trajectories of protein intake and age-specific protein intakes from 2 to 22 years with BMI in early adulthood. British Journal of Nutrition. 2017; 117:750-8.

6. Wu L, He LQ, Cui ZJ, Liu G, Yao K, Wu F, Li J, Li TJ. Effects of reducing dietary protein on the expression of nutrition sensing genes (amino acid transporters) in weaned piglets. J Zhejiang Univ Sci B. 2015; 16:496-502. https:// doi.org/10.1631/jzus.B1400259.

7. Yin Y, Tan B. Manipulation of dietary nitrogen, amino acids and phosphorus to reduce environmental impact of swine production and enhance animal health. J Food Agric Environ. 2010; 8:447-62.

8. Acciaioli A, Sirtori F, Pianaccioli L, Campodoni G, Pugliese C, Bozzi R, Franci O. Comparison of total tract digestibility and nitrogen balance between Cinta Senese and Large White pigs fed on different levels of dietary crude protein. Animal feed science and technology. 2011; 169:134-9. https://doi.org/10.1016/j.anifeedsci.2011.05.009.

9. Wu L, Liao P, He L, Ren W, Yin J, Duan J, Li T. Growth performance, serum biochemical profile, jejunal morphology, and the expression of nutrients transporter genes in deoxynivalenol (DON)- challenged growing pigs. BMC Vet Res. 2015; 11:144. https://doi.org/10.1186/ s12917-015-0449-y.

10. Wu L, Liao P, He L, Feng Z, Ren W, Yin J, Duan J, Li T, Yin Y. Dietary L-arginine supplementation protects weanling pigs from deoxynivalenol-induced toxicity. Toxins (Basel). 2015; 7:1341-54. https://doi.org/10.3390/toxins7041341.

11. Duan J, Yin J, Wu M, Liao P, Deng D, Liu G, Wen Q, Wang Y, Qiu W, Liu Y, Wu X, Ren W, Tan B, et al. Dietary glutamate supplementation ameliorates mycotoxin-induced abnormalities in the intestinal structure and expression of amino acid transporters in young pigs. PLoS One. 2014; 9:e112357. https://doi.org/10.1371/journal.pone.0112357.
12. Hahn JD, Biehl RR, Baker DH. Ideal digestible lysine level for early-and late-finishing swine. Journal of Animal Science. 1995; 73:773-84.

13. Kerr B, Easter R. Effect of feeding reduced protein, amino acid-supplemented diets on nitrogen and energy balance in grower pigs. Journal of Animal Science. 1995; 73:3000-8.

14. Figueroa J, Lewis A, Miller P, Fischer R, Gómez R, Diedrichsen R. Nitrogen metabolism and growth performance of gilts fed standard corn-soybean meal diets or low-crude protein, amino acid-supplemented diets. Journal of Animal Science. 2002; 80:2911-9.

15. Hansen JA, Knabe D, Burgoon K. Amino acid supplementation of low-protein sorghum-soybean meal diets for 20-to 50-kilogram swine. Journal of animal science. 1993; 71:442-51.

16. Gómez R, Lewis A, Miller P, Chen H. Growth performance, diet apparent digestibility, and plasma metabolite concentrations of barrows fed corn-soybean meal diets or low-protein, amino acid-supplemented diets at different feeding level. Journal of animal science. 2002; 80:644-53.

17. Silk D. Digestion and absorption of dietary protein in man. Proceedings of the Nutrition Society. 1980; 39:61-70.

18. Kendall DC, Gaines AM, Allee GL, Usry JL. Commercial validation of the true ileal digestible lysine requirement for eleven- to twenty-seven-kilogram pigs. J Anim Sci. 2008; 86:324-32. https://doi.org/10.2527/jas.2007-0086.

19. Kaji I, Akiba Y, Kaunitz J. Digestive Physiology of the Pig Symposium: Involvement of gut chemosensing in the regulation of mucosal barrier function and defense mechanisms. Journal of animal science. 2013; 91:1957-62.

20. Nishi T, Hara H, Hira T, Tomita F. Dietary protein peptic hydrolysates stimulate cholecystokinin release via direct sensing by rat intestinal mucosal cells. Experimental Biology and Medicine. 2001; 226:1031-6.

21. Liou A. Digestive physiology of the pig symposium: G protein-coupled receptors in nutrient chemosensation and gastrointestinal hormone secretion. Journal of animal science. 2013; 91:1946-56.

22. Ruan Z, Lv Y, Fu X, He Q, Deng Z, Liu W, Yingli Y, Wu X, Wu G, Wu X, Yin Y. Metabolomic analysis of amino acid metabolism in colitic rats supplemented with lactosucrose. Amino Acids. 2013; 45:877-87. https://doi.org/10.1007/ s00726-013-1535-8.

23. Liou AP. Digestive physiology of the pig symposium: $G$ protein-coupled receptors in nutrient chemosensation and gastrointestinal hormone secretion. J Anim Sci. 2013; 91:1946-56. https://doi.org/10.2527/jas.2012-5910.

24. Raybould HE. Gut chemosensing: interactions between gut endocrine cells and visceral afferents. Auton Neurosci. 2010; 153:41-6. https://doi.org/10.1016/j. autneu.2009.07.007.

25. Jagger S, Wiseman J, Cole D, Craigon J. Evaluation of inert markers for the determination of ileal and faecal apparent 
digestibility values in the pig. British Journal of Nutrition. 1992; 68:729-39.

26. Committee on Nutrition Requirements of Swine. (2012). Nutrient requirements of swine: Eleventh Revised Edition. (Washington, DC, USA: The National Academies Press).

27. Liao P, Li M, Li Y, Tan X, Zhao F, Shu X, Yin Y. Effects of dietary supplementation with cupreous $\mathrm{N}$-carbamylglutamate (NCG) chelate and copper sulfate on growth performance, serum biochemical profile and immune response, tissue mineral levels and fecal excretion of mineral in weaning piglets. Food and Agricultural Immunology. 2017; 28:1315-29.

28. Liao P, Li Y, Liu W. Preliminary shotgun glycoproteome analysis of $\mathrm{N}$-glycosylation sites in serum proteins of ricinintoxicated rats. Toxicological \& Environmental Chemistry. 2014; 96:1221-37.

29. Association of Official Analytical Chemists. Official methods of analysis of Association of Official Analytical Chemists, Arlington, VA, USA. 1990; 1:684.

30. Dai Z, Wu Z, Jia S, Wu G. Analysis of amino acid composition in proteins of animal tissues and foods as pre-column o-phthaldialdehyde derivatives by HPLC with fluorescence detection. J Chromatogr B Analyt Technol Biomed Life Sci. 2014; 964:116-27. https://doi. org/10.1016/j.jchromb.2014.03.025.

31. Cromwell G. Synthetic amino acid may improve performance, reduce nitrogen excretion. Feedstuffs (USA). 1996.

32. Tuitoek K, Young L, De Lange C, Kerr B. The effect of reducing excess dietary amino acids on growing-finishing pig performance: an elevation of the ideal protein concept. Journal of Animal Science. 1997; 75:1575-83.

33. Gallo L, Dalla Montà G, Carraro L, Cecchinato A, Carnier P, Schiavon S. Growth performance of heavy pigs fed restrictively diets with decreasing crude protein and indispensable amino acids content. Livestock Science. 2014; 161:130-8.

34. Morales A, Buenabad L, Castillo G, Vazquez L, Espinoza S, Htoo JK, Cervantes M. Dietary levels of protein and free amino acids affect pancreatic proteases activities, amino acids transporters expression and serum amino acid concentrations in starter pigs. J Anim Physiol Anim Nutr (Berl). 2017;101:723-732.

35. Li YH, Wei HK, Li FN, Kim SW, Wen CY, Duan YH, Guo QP, Wang WL, Liu HN, Yin YL. Regulation in free amino acid profile and protein synthesis pathway of growing pig skeletal muscles by low-protein diets for different time periods. J Anim Sci. 2016; 94:5192-205. https://doi. org/10.2527/jas.2016-0917.

36. Duan Y, Guo Q, Wen C, Wang W, Li Y, Tan B, Li F, Yin Y. Free Amino Acid Profile and Expression of Genes Implicated in Protein Metabolism in Skeletal Muscle of Growing Pigs Fed Low-Protein Diets Supplemented with Branched-Chain Amino Acids. J Agric Food Chem. 2016; 64:9390-400. https://doi.org/10.1021/acs.jafc.6b03966.
37. Nakamura Y, Katakai S, Hayakawa S, Kaneko S, Ishida K. Correlative evaluation of serum lipid, blood glucose, blood pressure, serum immunoreactive insulin, and liver function in persons undergoing regularly scheduled health evaluations. J Med Syst. 1993; 17:195-9.

38. Coma J, Carrion D, Zimmerman DR. Use of plasma urea nitrogen as a rapid response criterion to determine the lysine requirement of pigs. J Anim Sci. 1995; 73:472-81.

39. Heo JM, Kim JC, Hansen CF, Mullan BP, Hampson DJ, Pluske JR. Feeding a diet with decreased protein content reduces indices of protein fermentation and the incidence of postweaning diarrhea in weaned pigs challenged with an enterotoxigenic strain of Escherichia coli. J Anim Sci. 2009; 87:2833-43. https://doi.org/10.2527/jas.2008-1274.

40. Sink JD, Wilson LL, McCarthy RD, Rugh MC. Interrelationships between Serum Lipids, Energy Intake, Milk Production, Growth and Body Characteristics in Angus-Holstein Cows and their Progeny1. Journal of Animal Science. 1973; 36:313-7. https://doi.org/10.2527/ jas1973.362313x.

41. Kerr BJ, McKeith FK, Easter RA. Effect on performance and carcass characteristics of nursery to finisher pigs fed reduced crude protein, amino acid-supplemented diets. Journal of animal science. 1995; 73:433-40. https://doi. org/10.2527/1995.732433x.

42. Tous N, Lizardo R, Vilà B, Gispert M, Font-i-Furnols M, Esteve-Garcia E. Effect of reducing dietary protein and lysine on growth performance, carcass characteristics, intramuscular fat, and fatty acid profile of finishing barrows1. Journal of Animal Science. 2014; 92:129-40. https://doi.org/10.2527/jas.2012-6222.

43. Doran O, Moule SK, Teye GA, Whittington FM, Hallett $\mathrm{KG}$, Wood JD. A reduced protein diet induces stearoylCoA desaturase protein expression in pig muscle but not in subcutaneous adipose tissue: relationship with intramuscular lipid formation. Br J Nutr. 2006; 95:609-17.

44. Duan Y, Duan Y, Li F, Li Y, Guo Q, Ji Y, Tan B, Li T, Yin Y. Effects of supplementation with branched-chain amino acids to low-protein diets on expression of genes related to lipid metabolism in skeletal muscle of growing pigs. Amino Acids. 2016; 48:2131-44. https://doi.org/10.1007/ s00726-016-2223-2.

45. Kamran Z, Sarwar M, Nisa M, Nadeem M, Ahmad S, Mushtaq T, Ahmad T, Shahzad M. Effect of lowering dietary protein with constant energy to protein ratio on growth, body composition and nutrient utilization of broiler chicks. AsianAustralasian Journal of Animal Sciences. 2008; 21:1629-34.

46. Nukreaw R, Bunchasak C. Effect of supplementing synthetic amino acids in low-protein diet and subsequent re-feeding on growth performance, serum lipid profile and chemical body composition of broiler chickens. The Journal of Poultry Science. 2015; 52:127-36.

47. Agyekum A, Woyengo T, Slominski B, Yin Y, Nyachoti C. Effects of formulating growing pig diet with increasing levels of wheat-corn distillers dried grains with solubles 
on digestible nutrient basis on growth performance and nutrient digestibility. Journal of animal physiology and animal nutrition. 2014; 98:651-8.

48. Nelson G, Chandrashekar J, Hoon MA, Feng L, Zhao G, Ryba NJ, Zuker CS. An amino-acid taste receptor. Nature. 2002; 416:199-202.

49. Janssen S, Depoortere I. Nutrient sensing in the gut: new roads to therapeutics? Trends Endocrinol Metab. 2013; 24:92-100. https://doi.org/10.1016/j.tem.2012.11.006.

50. Tian ZM, Ma XY, Yang XF, Fan QL, Xiong YX, Qiu YQ, Wang L, Wen XL, Jiang ZY. Influence of low protein diets on gene expression of digestive enzymes and hormone secretion in the gastrointestinal tract of young weaned piglets. J Zhejiang Univ Sci B. 2016; 17:742-51. https:// doi.org/10.1631/jzus.B1600229.

51. Wang Y, Chandra R, Samsa LA, Gooch B, Fee BE, Cook JM, Vigna SR, Grant AO, Liddle RA. Amino acids stimulate cholecystokinin release through the $\mathrm{Ca} 2+$-sensing receptor. Am J Physiol Gastrointest Liver Physiol. 2011; 300:G52837. https://doi.org/10.1152/ajpgi.00387.2010.

52. San Gabriel A, Uneyama H. Amino acid sensing in the gastrointestinal tract. Amino Acids. 2013; 45:451-61. https://doi.org/10.1007/s00726-012-1371-2.

53. Ballinger AB, Clark ML. L-phenylalanine releases cholecystokinin (CCK) and is associated with reduced food intake in humans: evidence for a physiological role of CCK in control of eating. Metabolism. 1994; 43:735-8.

54. Mace OJ, Schindler M, Patel S. The regulation of K- and L-cell activity by GLUT2 and the calcium-sensing receptor CasR in rat small intestine. J Physiol. 2012; 590:2917-36. https://doi.org/10.1113/jphysiol.2011.223800.

55. Orozco-Solis R, Matos RJ, Guzman-Quevedo O, Lopes de Souza S, Bihouee A, Houlgatte R, Manhaes de Castro $\mathrm{R}$, Bolanos-Jimenez F. Nutritional programming in the rat is linked to long-lasting changes in nutrient sensing and energy homeostasis in the hypothalamus. PLoS One. 2010; 5:e13537. https://doi.org/10.1371/journal.pone.0013537.

56. Daly K, Al-Rammahi M, Moran A, Marcello M, Ninomiya Y, Shirazi-Beechey SP. Sensing of amino acids by the gut-expressed taste receptor T1R1-T1R3 stimulates CCK secretion. American Journal of Physiology-Gastrointestinal and Liver Physiology. 2013; 304:G271-G82.

57. Guzman-Pino SA, Sola-Oriol D, Figueroa J, Perez JF. Influence of the protein status of piglets on their ability to select and prefer protein sources. Physiol Behav. 2014; 129:43-9. https://doi.org/10.1016/j.physbeh.2014.02.029.

58. Perez-Jimenez A, Cardenete G, Morales AE, Garcia-Alcazar A, Abellan E, Hidalgo MC. Digestive enzymatic profile of Dentex dentex and response to different dietary formulations. Comp Biochem Physiol A Mol Integr Physiol. 2009; 154:157-64. https://doi.org/10.1016/j.cbpa.2009.05.126.

59. Barea R, Nieto R, Aguilera JF. Effects of the dietary protein content and the feeding level on protein and energy metabolism in Iberian pigs growing from 50 to $100 \mathrm{~kg}$ body weight. Animal. 2007; 1:357-65. https://doi.org/10.1017/ s1751731107666099.

60. Bikker P, Dirkzwager A, Fledderus J, Trevisi P, le HuerouLuron I, Lalles JP, Awati A. The effect of dietary protein and fermentable carbohydrates levels on growth performance and intestinal characteristics in newly weaned piglets. J Anim Sci. 2006; 84:3337-45. https://doi.org/10.2527/jas.2006-076.

61. Broer S. Amino acid transport across mammalian intestinal and renal epithelia. Physiol Rev. 2008; 88:249-86. https:// doi.org/10.1152/physrev.00018.2006.

62. Zhang S, Qiao S, Ren M, Zeng X, Ma X, Wu Z, Thacker $\mathrm{P}, \mathrm{Wu}$ G. Supplementation with branched-chain amino acids to a low-protein diet regulates intestinal expression of amino acid and peptide transporters in weanling pigs. Amino Acids. 2013; 45:1191-205. https://doi.org/10.1007/ s00726-013-1577-y. 